ISSN 2072-6694

Review

www.mdpi.com/journal/cancers

\title{
Cancer Stem Cells in Breast Cancer
}

\author{
Ryou-u Takahashi ${ }^{1}$, Fumitaka Takeshita ${ }^{1}$, Tomohiro Fujiwara ${ }^{1,2}$, Makiko Ono ${ }^{1}$ \\ and Takahiro Ochiya ${ }^{1, *}$
}

1 Division of Molecular and Cellular Medicine, National Cancer Center Research Institute, 1-1, Tsukiji 5-chome, Chuo-ku, Tokyo 104-0045, Japan; E-Mails: rytakaha@ncc.go.jp (R.T.); futakesh@ncc.go.jp (F.T.); tofujiwa@ncc.go.jp (T.F.); makono@ncc.go.jp (M.O.)

2 Department of Orthopedic Surgery, Okayama University Graduate School of Medicine, Dentistry, and Pharmaceutical Sciences, Okayama, Japan, 2-5-1 Shikata-cho, Okayama City, Okayama 700-8558, Japan

* Author to whom correspondence should be addressed; E-Mail: tochiya@ncc.go.jp; Tel.: +81-3-3542-2511 ext. 4800; Fax: +81-3-5565-0727.

Received: 17 February 2011; in revised form: 3 March 2011 / Accepted: 11 March 2011 / Published: 15 March 2011

\begin{abstract}
The cancer stem cell (CSC) theory is generally acknowledged as an important field of cancer research, not only as an academic matter but also as a crucial aspect of clinical practice. CSCs share a variety of biological properties with normal somatic stem cells in self-renewal, the propagation of differentiated progeny, the expression of specific cell markers and stem cell genes, and the utilization of common signaling pathways and the stem cell niche. However, CSCs differ from normal stem cells in their chemoresistance and their tumorigenic and metastatic activities. In this review, we focus on recent reports regarding the identification of CSC markers and the molecular mechanism of CSC phenotypes to understand the basic properties and molecular target of CSCs. In addition, we especially focus on the CSCs of breast cancer since the use of neoadjuvant chemotherapy can lead to the enrichment of CSCs in patients with that disease. The identification of CSC markers and an improved understanding of the molecular mechanism of CSC phenotypes should lead to progress in cancer therapy and improved prognoses for patients with cancer.
\end{abstract}

Keywords: cancer stem cells; breast cancer; EMT; TGF- $\beta$; microRNAs 


\section{Introduction}

To overcome problems related to conventional cancer therapy, many cancer researchers focus on tumor-initiating cells (TICs) or cancer stem cells (CSCs). The term CSC is frequently used to mean TIC. Although the CSC theory is well established and widely accepted [1-4], some controversies remain. CSCs, like normal stem cells, show asymmetric cell division [5,6], chemoresistance [7], and tumorigenicity [5]. CSCs have the capacity to form secondary/tertiary tumors upon serial xenotransplantation into immunodeficient rodents and show the same features as the original tumors. The demonstration of these three capacities, the gold standard for the evaluation of CSC phenotypes, reflects the malignancy of tumors and is critical in cancer therapy. Recent studies have demonstrated that CSCs show metastatic ability. In this article, we discuss the general features of CSCs and focus on their characteristics in breast cancers, in which the identification and analysis of CSC markers and CSC phenotypes are well refined.

\section{Origin of Cancer Stem Cells}

The development of fluorescent antibodies, flow cytometry, and associated cell sorting has facilitated the identification of the cell population that initiates tumors [5,6]. Furthermore, the development of mouse strains with profound immunodeficiencies has allowed the evaluation of tumor formation ability. With these developing tools, Dick and colleagues demonstrated that, in human acute myeloid leukemia (AML), a rare malignant cell showed the ability to repopulate the entire original disease over several transplantations and that such a cell population existed within the immature $\mathrm{CD} 34^{+} \mathrm{CD} 38^{-}$, and not the $\mathrm{CD} 34^{+} \mathrm{CD} 38^{+}$, sub-population [6]. Because of the similarity between $\mathrm{CD} 34^{+} \mathrm{CD} 38^{-}$cells and normal hematopoietic stem cells (HSCs), the origin of the cell population in which the disease arises was thought to be this normal population. Subsequent work with colony-formation assay and lentivirus vector tracking identified the cell population that was able to repopulate the disease not only over several transplantations but also over a single transplantation as quiescent stem cells [8]. This hierarchy, which closely mimics the normal process of hematopoietic precursor development, may explain the CSC biology of childhood AML [8].

\section{Solid Tumor CSCs}

The first solid CSCs were identified in breast tumors in 2003 [5]; subsequently, CSCs have been identified in brain [9,10], colon [11,12], melanoma [13,14], pancreatic [15,16], prostate [17], ovarian [18], hepatic [19], lung [20], and gastric cancers [21]. In breast cancer, CD44 ${ }^{+} \mathrm{CD} 24^{-/ \text {low }} \mathrm{ESA}^{+}$(epithelial surface antigen, also known as EpCAM) cells were identified as CSCs in a number of solid malignancies [5,22]. These cells are thought to share stem cell-like properties because they are capable of reconstituting the heterogeneity of the original primary tumors. The same approach was used for brain tumors exhibiting a subpopulation of $\mathrm{CD} 133^{+}$cells with CSC phenotypes $[9,10]$. CD133 ${ }^{+}$CSCs were subsequently isolated from colon and pancreatic cancers [23,24]. Recently, in hepatocellular carcinoma, EpCAM was identified as a CSC marker and found to be expressed in normal epithelial progenitor cells [25]. Furthermore, aldehyde dehydrogenase (ALDH) is a CSC marker in breast 
cancers [26]. The representative cell surface markers for human hematologic and solid cancers reported to date are listed in Table 1.

Table1. Representative Cell Surface Markers for Human Cancer Stem Cells (CSCs).

\begin{tabular}{|c|c|c|}
\hline Cancer Type & Cell Surface Markers & Ref. \\
\hline AML & $\mathrm{CD} 34^{+} \mathrm{CD} 38^{-}$ & [6] \\
\hline \multirow{2}{*}{ Breast Cancer } & $\mathrm{ESA}^{+} / \mathrm{CD} 44^{+} / \mathrm{CD} 24^{-/ \text {low }}$ & [5] \\
\hline & ALDH1 & [26] \\
\hline Glioma & CD133 & {$[9,10]$} \\
\hline Colon Cancer & CD133 & {$[11,12]$} \\
\hline Metastatic Colon Cancer & $\mathrm{CD} 133^{+} / \mathrm{CD} 26^{+}$ & [27] \\
\hline \multirow{2}{*}{ Melanoma } & $\mathrm{CD} 20$ & [13] \\
\hline & $\mathrm{CD} 271$ & [14] \\
\hline Pancreatic Cancer & $\mathrm{ESA}^{+} / \mathrm{CD} 44^{+} / \mathrm{CD} 24^{+}$ & [16] \\
\hline Metastatic Pancreatic Cancer & $\mathrm{CD}_{133}{ }^{+} / \mathrm{CXCR} 4^{+}$ & [15] \\
\hline Prostate Cancer & $\mathrm{CD} 44^{+} / \alpha_{2} \beta_{1}{ }^{+} / \mathrm{CD} 133^{+}$ & [17] \\
\hline \multirow{2}{*}{ Ovarian Cancer } & $\mathrm{CD} 44^{+} / \mathrm{CD} 117^{+}$ & [28] \\
\hline & $\mathrm{CD}_{4} 4^{+} \mathrm{MYD} 8^{+}$ & [29] \\
\hline Hepatic Cancer & EpCAM & [25] \\
\hline Lung Cancer & CD133 & [20] \\
\hline Gastric Cancer & $\mathrm{CD} 44$ & [21] \\
\hline
\end{tabular}

AML: Acute myeloid leukemia; CXCR4: Chemokine receptor 4; ESA: Epithelial surface antigen; ALDH: Aldehyde dehydrogenase $1 \mathrm{~A} 1 ; \alpha_{2} \beta_{1}$ : Integrin $\alpha_{2} \beta_{1}$; MYD88: Myeloid differentiation primary response protein Myd88

\section{CSC Markers}

\subsection{Side Population}

Following the identification of the Hoechst 33342 dye-efflux side population (SP) in bone marrow cells in mice as hematopoietic stem cells [30,31], SP cells with stem cell-like properties have been identified in a variety of human hematologic cells and solid malignant cells. These cells show CSC phenotypes characterized by asymmetric cell division, drug resistance, and tumorigenicity [16,32-34]. Thus, SP cells can be assumed to play important roles in CSC fractions. Zhou et al. demonstrated that the expression of the $A B C G 2$ gene, a member of the ATP binding cassette (ABC) transporter superfamily, is an important determinant of the SP phenotype [35].

A recent study pointed out the following problems in using SP cells as a CSC fraction [36]. First, cells resistant to Hoechst 33342 dye do not necessarily show tumorigenicity and metastatic ability as CSCs. For example, ABCG2-positive MCF-7 cells showed no more tumorigenic potential than did ABCG2-negative cells [37]. Second, the staining condition, staining time, and cellular concentration of Hoechst dye affect the viability of the SP fraction [36]. Third, cytometry gating strategies used to isolate SP cells lack the consistency of gating strategies used in marker staining [36]. These problems latently lead to cross-contamination of the SP and the non-SP fractions, resulting in controversial data. 


\section{2. $C D 34$}

CD34 is a monomeric cell-surface antigen with a molecular mass of approximately $110 \mathrm{kD}$ [6]. In common acute lymphoblastic leukemia (CALL), the expression of CD34 is positively correlated with CD10, known as common acute lymphocytic leukemia antigen (CALLA) [38]. CD34-positive leukemic cells are thought to be a less-differentiated phenotype than CD34-negative cells [6]. CD10 is a key element in the niche that maintains the progenitor and stem cell pools in the mammary lineage [39].

\section{3. $C D 44$}

CD44 is a useful marker for collecting CSCs not only in breast tumors but also in a variety of other tumor models [5,40,41]. CD44 may also be important in metastasis. Through the implantation of patient tumors or breast CSCs into mouse mammary fat pads and the use of noninvasive imaging strategies, it was demonstrated that $\mathrm{CD} 44^{+}$cells from both primary tumors and lung metastases showed high tumorigenicity [42]. In addition, CD44 variant isoforms are differentially expressed during pregnancy and involution, indicating a role in normal breast epithelial homeostasis [43]. p53 inhibits the expression of the CD44 cell-surface molecule via binding to a noncanonical p53-binding sequence in the CD44 promoter [44]. This interaction enables an untransformed cell to respond to stress-induced, p53-dependent cytostatic and apoptotic signals that would otherwise be blocked by the actions of CD44 [44].

\section{4. $C D 133$}

As shown in Table 1, recent studies have demonstrated that CD133 (prominin-1) is a specific marker of CSCs in a wide spectrum of malignant tumors [10,12,24]. CD133 was the first identified member of the prominin family of the 5-transmembrane glycoprotein [45]. In 1997, Yin et al. produced a novel monoclonal antibody (MAb) that recognized the AC133 antigen [46], a glycosylation-dependent epitope of CD133, and the expression of AC133 restricted in CD34 progenitor cells from adult blood [47]. CD133 cDNA encodes a 5-transmembrane domain molecule with an extracellular N-terminus, a cyotoplasmic C-terminus, and two large extracellular loops with eight consensus sites for $N$-linked glycosylation [48]. The characteristic feature of CD133 is its rapid downregulation during cell differentiation [49]. This feature makes CD133 a unique cell surface marker for the identification and isolation of stem cells and progenitor cells in several tissues [45]. According to the CSC theory, CSCs express some stem cell markers as normal stem cells [1,2]. Therefore, tumor cells expressing CD133 independently or in combination with other stem or progenitor cell markers are thought to represent CSCs.

\subsection{Aldehyde Dehydrogenase (ALDH)}

ALDH1 is a detoxifying enzyme responsible for the oxidation of intracellular aldehydes [50]. ALDH has been reported to have a role in the early differentiation of stem cells in the oxidization of retinol to retinoic acid [51,52]. Furthermore, high ALDH activity has been observed in murine and human hematopoietic and neural stem and progenitor cells [53,54]. An increase in ALDH activity has also been found in stem cell populations in multiple myeloma and AML [55]. Therefore, ALDH 
activity may provide a common marker for both normal and malignant stem and progenitor cells. In several tumors, the measurement of ALDH activity is a useful approach in the identification and isolation of CSCs [56-59]. However, the ALDEFLUOR assay does have some limitations in the isolation of the most tumorigenic population, notably in tumors of different origins. For example, both ALDEFLUOR (bright) and ALDEFLUOR (low) from the melanoma cell line were able to initiate tumors after inoculation into NOD/SCID mice [60]. Moreover, tumors generated from ALDEFLUOR (low) cells grew faster and bigger than tumors from ALDEFLUOR (bright), even among passages. These results suggest that the ALDEFLUOR-positive population in melanoma is not stem cell-enriched, unlike the ALDEFLUOR-negative population [60]. Furthermore, the stem cell population identified using the ALDEFLUOR assay is probably heterogeneous and needs to be dissected using additional markers.

\section{6. microRNA}

Despite progress in the identification of CSC markers, the CSC theory has been complicated by a lack of clearly defined developmental surface markers specific for individual tumor types, making the molecular mechanism of common phenotypes in CSC fractions the object of much ongoing research. In this regard, microRNAs (miRNAs), as a part of non-coding RNA, are considered to be novel markers for CSCs, as shown in Table 2.

Table 2. miRNAs Regulate the CSC Phenotypes.

\begin{tabular}{|clcc|}
\hline Cancer Type & microRNA & Potential Targets & Ref. \\
\hline Breast Cancer & let-7 & H-Ras and HMGA2 & {$[61]$} \\
& miR-200c & BMI1 & {$[62]$} \\
& let-7 & IL-6 & {$[63]$} \\
& miR-200b & Suz12 & {$[64]$} \\
\hline Glioblastoma & miR-199b-5p & HES1 & {$[65]$} \\
& miR-34a & c-Met, Notch1, and Notch2 & {$[66]$} \\
& miR-328 & ABCG2 & {$[67]$} \\
\hline Medulloblastoma & miR128a & BMI1 & {$[68]$} \\
\hline Hepatic Cancer & miR-181 & CDX2, GATA6, and NLK & {$[69]$} \\
\hline Pancreatic Cancer & miR-34s & Bcl2 and Notch & {$[70]$} \\
\hline Osteosarcoma and & miR-140 & HDAC4 & {$[71]$} \\
Colon Cancer & miR-215 & DHFR and Thymidylate synthase & {$[72]$} \\
\hline
\end{tabular}

HMGA2: High mobility group AT-hook2; BMI1: BMI1 Polycomb ring finger oncogene; IL-6: Interleukin 6; SUZ12: Suppressor of zest 12 homolog; HES1: Hairy and enhancer of split 1; CDX2: Caudal type homeobox

2; GATA6: Gata binding protein 6; NLK: Nemo-like kinase 6; HDAC4: Histone deacetylase 4; DHFR: Dihydrofolate reductase

\section{Breast Cancer Stem Cells (BCSCs)}

\subsection{Identification of BCSCs}

The pioneering study by Clarke and colleagues used breast cancer xenografts to isolate a population of cells able to initiate tumors in NOD/SCID mice [5]. This population was defined by the combined 
expression of the cell surface marker $\mathrm{CD} 44^{+} / \mathrm{CD} 24^{-/ \mathrm{low}} / \mathrm{lin}^{-}$. As few as 200 of these cells generated tumors in NOD/SCID mice, whereas 20,000 cells that did not display this phenotype failed to do so. The NOD/SCID tumors recapitulated the entire heterogeneity of the initial tumor. Furthermore, the $\mathrm{CD} 44^{+} / \mathrm{CD} 24^{-/ \mathrm{low}} / \mathrm{lin}^{-}$cell population was able to reinitiate tumors in NOD/SCID mice and retained this ability after serial passages. Thus, these cells, which had the ability to self-renew and to differentiate and which displayed tumorigenic capacity, had CSC features.

Through the use of the $\mathrm{CD} 44^{+} / \mathrm{CD} 24^{-/ \text {low }} / \mathrm{lin}^{-}$phenotype and another marker, the ALDEFLUOR assay, it has been shown that cells able to initiate tumors in mice are among the ALDEFLUOR-positive cells, the cells displaying both phenotypes being the most tumorigenic, and that none of the $\mathrm{CD} 44^{+} / \mathrm{CD} 24^{-/ \text {low }} / \mathrm{lin}^{-}$cells without ALDEFLUOR activity can grow in mice [26]. These results indicate that the $\mathrm{CD} 44^{+} / \mathrm{CD} 24^{-/ \mathrm{low}} / \mathrm{lin}^{-}$population contains some but not all of the CSCs in breast tumors. Moreover, while CD44 appears to be a common stem cell marker [73-75], as well as a promising therapeutic target [76,77], the $\mathrm{CD} 44^{+} / \mathrm{CD} 24^{-/ \mathrm{low}} / \mathrm{lin}^{-}$phenotype is probably tissue restricted. For example, pancreatic cancer cells with stem cell properties of self-renewal, the ability to produce differentiated progeny, and increased expression of the developmental signaling molecule sonic hedgehog display a $\mathrm{CD} 44^{+} / \mathrm{CD} 24^{+} / \mathrm{ESA}^{+}$phenotype $[16,78]$.

\subsection{Epithelial-Mesenchymal Transition (EMT)}

Pathophysiological conditions such as tissue injury or tumorigenesis can trigger differentiated cells to acquire a multipotent stem cell-like phenotype through EMT induction [32,79]. This acquisition may mirror developmentally regulated EMT signaling pathways, such as Wnt, Notch, and Hedgehog, which drive both normal and CSC renewal and maintenance [32,80,81]. Metastatic cancer cells, which have presumably undergone EMT, may exhibit CSC phenotypes. For instance, in murine and human melanoma, cancer metastasis is accelerated through immunosuppression during Snail-induced EMT [82]. A recent study revealed a subpopulation of $\mathrm{CD} 26^{+}$cancer stem cells showing not only chemoresistance but also metastatic potential in human colorectal cancer [27]. In breast tumors, CD $44^{+}$cells from both primary tumors and lung metastases are highly enriched for tumor-initiating cells [42].

Empirical evidence connecting EMT to the acquisition of stem cell phenotypes has recently been reported by Weinberg et al. [83]. The differentiated mammary epithelial cells that have undergone EMT either on transforming growth factor beta (TGF- $\beta$ ) treatment or by the expression of E-cadherin transcriptional repressors, such as Snail or Twist, generate CD $44^{+} / \mathrm{CD} 24^{-}$cells as BCSCs [83]. The same researchers also demonstrated that E-cadherin knockdown generated $\mathrm{CD} 44^{+} / \mathrm{CD} 24^{-}$cells showing BCSC properties [7]. In addition, stem cells isolated from normal breast tissue or breast cancers express a number of canonical EMT markers [83]. Of clinical significance, an immune response that induces the EMT-associated emergence of CSCs as $\mathrm{CD} 8^{+} \mathrm{T}$-cells can induce the dedifferentiation of breast cancer cells, resulting in the generation of $\mathrm{CD} 44^{+} / \mathrm{CD} 24^{-}$stem cell-like cells [84]. In summary, accumulating evidence links EMT to the generation of CSC-like phenotypes, which may be prerequisites for cancer cell metastasis. 


\section{3. $T G F-\beta$}

TGF- $\beta$ family cytokines are mediators of embryonic development and tissue homeostasis in adults [85]. TGF- $\beta$ signaling controls many types of physiological and pathophysiological EMT $[79,86]$. Type I and type II TGF- $\beta$ receptors (T $\beta$ RI and RII, respectively) are dual specificity kinases that possess both serine/threonine and tyrosine kinase activities [87]. T $\beta$ RI activates effector Smads 2 and 3, which subsequently bind to a co-smad, Smad4. The Smad2, Smad3, and Smad4 complexes can associate with accessory transcription factors to activate the expression of target genes that cause changes in cellular differentiation. Notably, Smads associate with zinc finger E-box binding (ZEB) proteins to repress the expression of E-cadherin during the initiation of EMT [88-91]. TGF- $\beta$ suppresses tumor growth strongly and induces apoptotic effects during the early stages of tumor progression. However, tumors show that EMT becomes insensitive to TGF- $\beta$-mediated growth inhibition while showing increased tumor invasion and metastasis. Significant progress has been made in the elucidation of the cellular and molecular events that regulate tumor-promoting effects on microenvironments and tumor cells. Indeed, in breast cancer, mesenchymal stem cell (MSC)-derived TGF- $\beta 1$ increases the frequency of regulatory $\mathrm{T}$ cells, resulting in the support of breast cancer growth [92]. TGF- $\beta$ signaling is also reported to regulate the expression and activity of matrix metalloproteases (MMP-2 and MMP-9) and downregulate the expression of the protease inhibitor TIMP in tumor and endothelial cells [93]. Furthermore, recent work has uncovered an intricate new mechanism through which TGF- $\beta$ acts in concert with oncogenic Ras to antagonize the p63-metastasis protective function [94]. p63 inhibition requires the combined action of Ras-activated mutant p53 and TGF $\beta$-induced Smads, mechanistically involving the formation of a p63-Smads-mutant p53 ternary complex. Remarkably, two of the key downstream targets (cyclin G2 and SHARP1) of p63 are prognostic tools for breast cancer metastasis.

\subsection{MicroRNAs (miRNAs) in Regulation of BCSCs}

The emergence of miRNAs as important players in breast cancer has led researchers to explore the molecular mechanism that regulates BCSC phenotypes [61-63]. Some miRNAs play important roles in the phenotype formation of BCSCs, and multiple targets of these miRNAs have been identified [95,96] (Figure 1). Let-7 was originally identified in the nematode Caenorhabditis elegans [97,98]. Subsequently, the conservation of the let-7 sequence and its function in mammals were reported. Let-7 was one of the most consistently and significantly reduced miRNAs in many types of tumors, and downreglation of its expression was associated with the progression of tumor malignancy [99]. Recent studies have shown that let-7 suppresses self-renewal in both normal cells and BCSCs. Let-7 also regulates BCSC phenotypes such as chemoresistance and asymmetric cell division [61]. Several oncogenes, including c-Myc, Ras, HMGA2, cyclin D, and IL-6, have been reported as the targets of let-7 [61,63,99]. HMGA2 and Ras are highly expressed in BCSCs and remarkably repressed in non-BCSCs [61]. A comprehensive pathway involved in let-7 and lin-28 promotes the tumor metastasis and BCSC-induced inflammatory response [63]. Lin-28 is a highly specific embryonic stem cell marker and behaves as a negative regulator of let-7. Let-7 also directly represses lin-28 expression in ES and cancer cells [100]. 
In a comparison of the miRNA expression profiles of BCSCs and non-CSCs from human breast tumor samples, some miRNAs were upregulated and downregulated in BCSCs [62]. Three clusters, miR-200c-141, miR-200b-200a-429, and miR-183-96-182, were downregulated in human BCSCs [62]. Further study demonstrated that miR-200c regulated BCSC phenotypes by regulating the expression of BMI1, a member of the polycomb group of proteins, and acted as a negative regulator of stem cell phenotypes such as apoptosis, senescence, and differentiation [62].

miR-9, which is upregulated in breast cancer cells, directly targets $\mathrm{CDH} 1$, the E-cadherin-encoding messenger RNA, and also promotes cell motility and invasiveness [101]. miR-9-mediated E-cadherin downregulation results in the activation of beta-catenin signaling, which contributes to the upregulated expression of the gene encoding vascular endothelial growth factor (VEGF), which increases tumor angiogenesis [101]. Expression of miR-9 is activated by MYC and MYCN, both of which directly bind to the mir-9-3 locus. Significantly, in human cancers, miR-9 levels correlate with MYCN amplification, tumor grade, and metastatic status [101].

Thus, the dysregulation of miRNA is responsible for the BCSC phenotypes in the malignant progression of breast cancer, and the elucidation of the precise molecular mechanism may be the next step toward a more complete understanding of the regulatory networks underlying BCSC phenotypes, including metastasis.

Figure 1. miRNA regulates BCSC phenotypes. Let-7 [61], miR-30 [102], and miR-200 [62] may regulate BCSC phenotypes by modulating the expression of their target genes. The expression of let-7, miR-30, and miR-200 is remarkably reduced in BCSCs, progressively increased with the differentiation of BCSCs, and inversely correlated with the expression of their target genes. miR-9 [101], miR-328 [67], miR-373 and miR-520c [103] also regulate $\mathrm{BCSC}$ phenotypes.

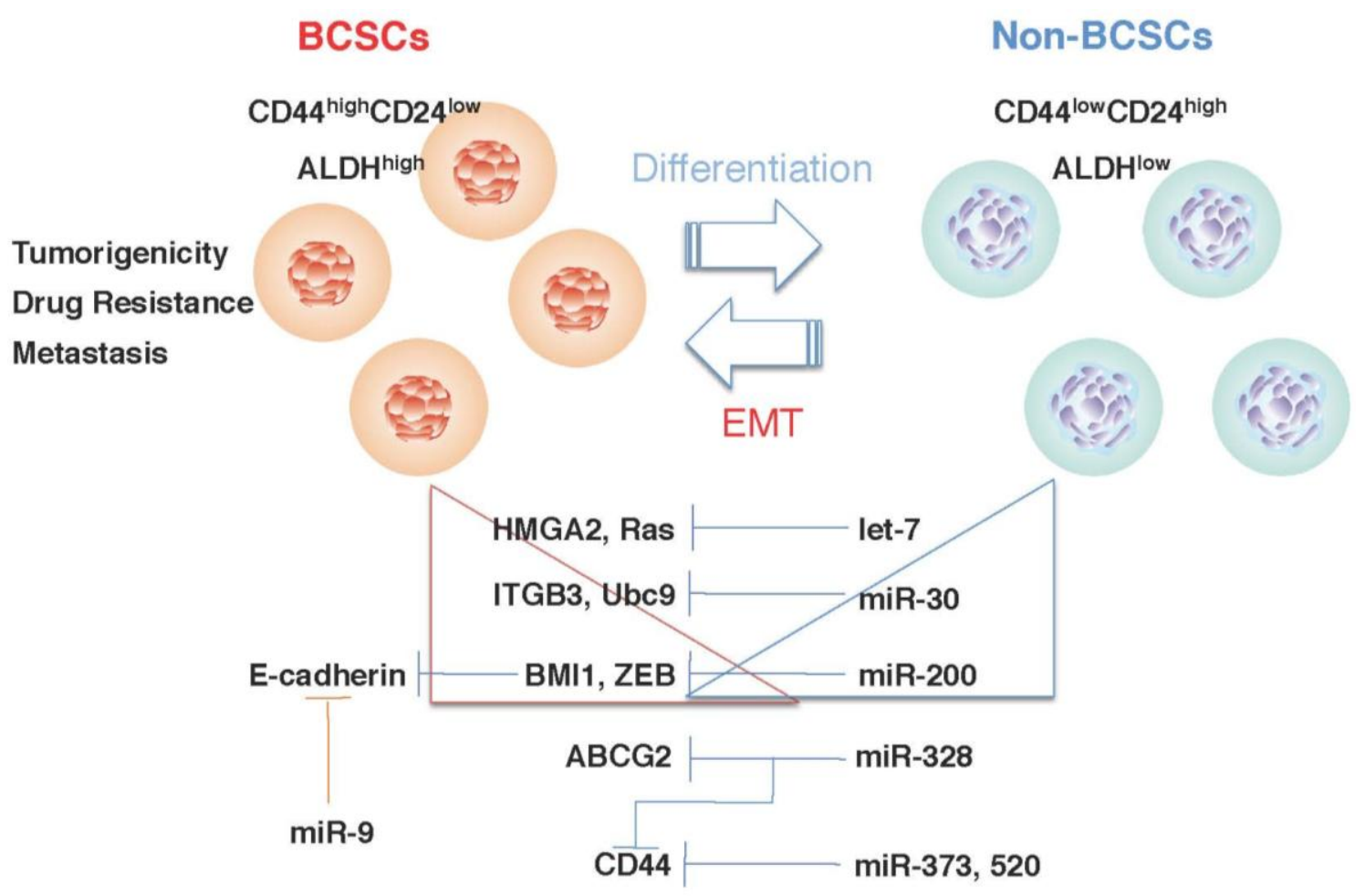




\section{CSC-Related Therapy}

The development of therapies against CSCs is challenging because both bulk tumor cells and CSCs must be eliminated. As CSCs are molecularly distinct from bulk tumor cells, one can target their activity by exploiting the molecular differences [76,104-107]. For instance, cell surface marker expression could be used for antibody-directed therapy to target proteins, such as CD133, CD44, or ABC transporters, which are ATP-dependent drug efflux pumps [76,104-106]. A recent study identified ribophorin II (RPN2), part of an $N$-oligosaccharyl transferase complex, as a novel regulator of drug resistance via the regulation of the $N$-linked glycosylation of ABCB1 (P-glycoprotein) in breast cancer [107]. The downregulation of RPN2 most efficiently induces apoptosis of drug-resistant breast cancer cells in the presence of docetaxel. However, prior to developing an anti RPN2 therapy against cancer stem cells, the safety of the effect of RPN2 silencing in normal tissue stem cells should be tested.

Another strategy to selectively target CSCs is high-throughput compound screening. In one study, the antibiotic salinomycin preferentially killed BCSCs [7]. Interestingly, salinomycin induced the differentiation of BCSCs in vivo, as assessed by increased E-cadherin and reduced vimentin expression [7]. Furthermore, a recent study showed that salinomycin effectively reduced the number of P-glycoprotein expressing cells [108]. The activation of AMP-activated kinase with the diabetes drug metformin also resulted in the selective killing of CSCs in combination with chemotherapy [109]. This finding suggests that targeting mTOR activity, which is negatively regulated by AMP-activated kinase, may be a strategy to block BCSC phenotypes [110,111].

Recent studies have shown that oncolytic viruses seem to be well suited to eliminate CSCs because the viruses are cytotoxic and are not subject to drug efflux such as $\mathrm{ABC}$ transporters and defective apoptotic signaling [112]. These viruses are emerging as novel tools for cancer therapy, and several are already in clinical trials [113,114]. Virotherapy can also be utilized to sensitize tumor cells to radiation and chemotherapy and as tools for immunotherapy [115]. Thus, oncolytic viruses have significant advantages for improved treatment options for patients. In breast cancer, capsid-modified adenovirus vectors and reovirus vectors are effective for the elimination of BCSCs [116,117]. A recent study showed that BCSCs had dysregulated innate immune responses caused by impaired trafficking of toll-like receptor 9 (TLR9) and cofactor MyD88 and the absence of TLR2, resulting in dysfunctional virus recognition. These defects induced the dysfunctional induction of the type I interferon (IFN) response in BCSCs, leading to permissivity to the oncolytic adenovirus [118].

\section{Conclusions}

As accumulating evidence demonstrates that cancers are heterogeneous, clinical oncologists and cancer researchers need to consider which cancer cells have the potential to contribute to disease progression, including drug resistance and metastasis. Moreover, in breast cancer, recent studies have shown that non-CSCs acquire the CSC phenotype through EMT. Several key signaling pathways contribute to this process, namely, TGF- $\beta$ and Wnt, known inducers of EMT and promoters of stem cell maintenance. The microRNAs also play critical roles in these processes, and the dysregulation of microRNA expression is likely to be a major contributing factor in CSC phenotypes. Therefore, targeting EMT pathways and CSC maintenance is a promising therapeutic strategy, one that seems to 
be feasible since several studies have successfully shown that pharmacological agents can modulate the differentiation state of a tumor. Thus, 'differentiation-inducing' agents such as salinomycin or metformin may have therapeutic value. The use of a natural miRNA to suppress the CSC phenotypes also promises to lead to a new therapeutic strategy for the treatment of CSCs.

Finally, the CSC phenotypes, which lead to high tumorigenicity, drug resistance, and metastasis, are responsible for many problems affecting cancer patients. Therefore, understanding and overcoming the CSC phenotypes will improve conventional cancer therapy.

\section{Acknowledgments}

This work was supported in part by a grant-in-aid for the Third-Term Comprehensive 10-Year Strategy for Cancer Control of Japan; a grant-in-aid for Scientific Research on Priority Areas Cancer from the Japanese Ministry of Education, Culture, Sports, Science, and Technology; and the Program for Promotion of Fundamental Studies in Health Sciences of the National Institute of Biomedical Innovation of Japan.

\section{References}

1. Clarke, M.F.; Dick, J.E.; Dirks, P.B.; Eaves, C.J.; Jamieson, C.H.; Jones, D.L.; Visvader, J.; Weissman, I.L.; Wahl, G.M. Cancer stem cells-Perspectives on current status and future directions: AACR Workshop on cancer stem cells. Cancer Res. 2006, 66, 9339-9344.

2. Lobo, N.A.; Shimono, Y.; Qian, D.; Clarke, M.F. The biology of cancer stem cells. Annu. Rev. Cell Dev. Biol. 2007, 23, 675-699.

3. Kim, C.F.; Dirks, P.B. Cancer and stem cell biology: how tightly intertwined? Cell Stem Cell 2008, 3, 147-150.

4. Li, X.; Lewis, M.T.; Huang, J.; Gutierrez, C.; Osborne, C.K.; Wu, M.F.; Hilsenbeck, S.G.; Pavlick, A.; Zhang, X.; Chamness, G.C.; Wong, H.; Rosen, J.; Chang, J.C. Intrinsic resistance of tumorigenic breast cancer cells to chemotherapy. J. Natl. Cancer Inst. 2008, 100, 672-679.

5. Al-Hajj, M.; Wicha, M.S.; Benito-Hernandez, A.; Morrison, S.J.; Clarke, M.F. Prospective identification of tumorigenic breast cancer cells. Proc. Natl. Acad. Sci. USA 2003, 100, 3983-3988.

6. Bonnet, D.; Dick, J.E. Human acute myeloid leukemia is organized as a hierarchy that originates from a primitive hematopoietic cell. Nat. Med. 1997, 3, 730-737.

7. Gupta, P.B.; Onder, T.T.; Jiang, G.; Tao, K.; Kuperwasser, C.; Weinberg, R.A.; Lander, E.S. Identification of selective inhibitors of cancer stem cells by high-throughput screening. Cell 2009, 138, 645-659.

8. Hope, K.J.; Jin, L.; Dick, J.E. Acute myeloid leukemia originates from a hierarchy of leukemic stem cell classes that differ in self-renewal capacity. Nat. Immunol. 2004, 5, 738-743.

9. Hemmati, H.D.; Nakano, I.; Lazareff, J.A.; Masterman-Smith, M.; Geschwind, D.H.; Bronner-Fraser, M.; Kornblum, H.I. Cancerous stem cells can arise from pediatric brain tumors. Proc. Natl. Acad. Sci. USA 2003, 100, 15178-1583.

10. Singh, S.K.; Clarke, I.D.; Terasaki, M.; Bonn, V.E.; Hawkins, C.; Squire, J.; Dirks, P.B. Identification of a cancer stem cell in human brain tumors. Cancer Res. 2003, 63, 5821-5828. 
11. O'Brien, C.A.; Pollett, A.; Gallinger, S.; Dick, J.E. A human colon cancer cell capable of initiating tumour growth in immunodeficient mice. Nature 2007, 445, 106-110.

12. Ricci-Vitiani, L.; Lombardi, D.G.; Pilozzi, E.; Biffoni, M.; Todaro, M.; Peschle, C.; De Maria, R. Identification and expansion of human colon-cancer-initiating cells. Nature 2007, 445, 111-115.

13. Fang, D.; Nguyen, T.K.; Leishear, K.; Finko, R.; Kulp, A.N.; Hotz, S.; Van Belle, P.A.; Xu, X.; Elder, D.E.; Herlyn, M. A tumorigenic subpopulation with stem cell properties in melanomas. Cancer Res. 2005, 65, 9328-9337.

14. Boiko, A.D.; Razorenova, O.V.; van de Rijn, M.; Swetter, S.M.; Johnson, D.L.; Ly, D.P.; Butler, P.D.; Yang, G.P.; Joshua, B.; Kaplan, M.J.; Longaker, M.T.; Weissman, I.L. Human melanoma-initiating cells express neural crest nerve growth factor receptor CD271. Nature 2010, 466, 133-137.

15. Hermann, P.C.; Huber, S.L.; Herrler, T.; Aicher, A.; Ellwart, J.W.; Guba, M.; Bruns, C.J.; Heeschen, C. Distinct populations of cancer stem cells determine tumor growth and metastatic activity in human pancreatic cancer. Cell Stem Cell 2007, 1, 313-323.

16. Li, C.; Heidt, D.G.; Dalerba, P.; Burant, C.F.; Zhang, L.; Adsay, V.; Wicha, M.; Clarke, M.F.; Simeone, D.M. Identification of pancreatic cancer stem cells. Cancer Res. 2007, 67, 1030-1037.

17. Collins, A.T.; Berry, P.A.; Hyde, C.; Stower, M.J.; Maitland, N.J. Prospective identification of tumorigenic prostate cancer stem cells. Cancer Res. 2005, 65, 10946-51.

18. Bapat, S.A.; Mali, A.M.; Koppikar, C.B.; Kurrey, N.K. Stem and progenitor-like cells contribute to the aggressive behavior of human epithelial ovarian cancer. Cancer Res. 2005, 65, 3025-3029.

19. Ishikawa, K.; Sasaki, A.; Haraguchi, N.; Yoshikawa, Y.; Mori, M. A case of an alpha-fetoprotein-producing intrahepatic cholangiocarcinoma suggests probable cancer stem cell origin. Oncologist 2007, 12, 320-324.

20. Eramo, A.; Lotti, F.; Sette, G.; Pilozzi, E.; Biffoni, M.; Di Virgilio, A.; Conticello, C.; Ruco, L.; Peschle, C.; De Maria, R. Identification and expansion of the tumorigenic lung cancer stem cell population. Cell Death Differ. 2008, 15, 504-514.

21. Takaishi, S.; Okumura, T.; Tu, S.; Wang, S.S.; Shibata, W.; Vigneshwaran, R.; Gordon, S.A.; Shimada, Y; Wang, T.C. Identification of gastric cancer stem cells using the cell surface marker CD44. Stem Cells 2009, 27, 1006-1020.

22. Fillmore, C.M.; Kuperwasser, C. Human breast cancer cell lines contain stem-like cells that self-renew, give rise to phenotypically diverse progeny and survive chemotherapy. Breast Cancer Res. 2008, 10, R.25.

23. Vermeulen, L.; Todaro, M.; de Sousa Mello, F.; Sprick, M.R.; Kemper, K.; Perez Alea, M.; Richel, D.J.; Stassi, G.; Medema, J.P. Single-cell cloning of colon cancer stem cells reveals a multi-lineage differentiation capacity. Proc. Natl. Acad. Sci. USA 2008, 105, 13427-13432.

24. Maeda, S.; Shinchi, H.; Kurahara, H.; Mataki, Y.; Maemura, K.; Sato, M.; Natsugoe, S.; Aikou, T.; Takao, S. CD133 expression is correlated with lymph node metastasis and vascular endothelial growth factor-C expression in pancreatic cancer. Br. J. Cancer 2008, 98, 1389-1397.

25. Yamashita, T.; Honda, M.; Nio, K.; Nakamoto, Y.; Yamashita, T.; Takamura, H.; Tani, T.; Zen, Y.; Kaneko, S. Oncostatin $\mathrm{m}$ renders epithelial cell adhesion molecule-positive liver cancer stem cells sensitive to 5-Fluorouracil by inducing hepatocytic differentiation. Cancer Res. 2010, 70, 4687-497. 
26. Ginestier, C.; Hur, M.H.; Charafe-Jauffret, E.; Monville, F.; Dutcher, J.; Brown, M.; Jacquemier, J.; Viens, P.; Kleer, C.G.; Liu, S.; Schott, A.; Hayes, D.; Birnbaum, D.; Wicha, M.S.; Dontu, G. ALDH1 is a marker of normal and malignant human mammary stem cells and a predictor of poor clinical outcome. Cell Stem Cell 2007, 1, 555-567.

27. Pang, R.; Law, W.L.; Chu, A.C.; Poon, J.T.; Lam, C.S.; Chow, A.K.; Ng, L.; Cheung, L.W.; Lan, X.R.; Lan, H.Y.; Tan, V.P.; Yau, T.C.; Poon, R.T.; Wong, B.C. A subpopulation of CD26+ cancer stem cells with metastatic capacity in human colorectal cancer. Cell Stem Cell 2010, 6, 603-615.

28. Zhang, S.; Balch, C.; Chan, M.W.; Lai, H.C.; Matei, D.; Schilder, J.M.; Yan, P.S.; Huang, T.H.; Nephew, K.P. Identification and characterization of ovarian cancer-initiating cells from primary human tumors. Cancer Res. 2008, 68, 4311-4320.

29. Alvero, A.B.; Chen, R.; Fu, H.H.; Montagna, M.; Schwartz, P.E.; Rutherford, T.; Silasi, D.A.; Steffensen, K.D.; Waldstrom, M.; Visintin, I.; Mor, G. Molecular phenotyping of human ovarian cancer stem cells unravels the mechanisms for repair and chemoresistance. Cell Cycle 2009, 8, 158-166.

30. Goodell, M.A.; Brose, K.; Paradis, G.; Conner, A.S.; Mulligan, R.C. Isolation and functional properties of murine hematopoietic stem cells that are replicating in vivo. J. Exp. Med. 1996, 183, 1797-1806.

31. Ibrahim, S.F.; Diercks, A.H.; Petersen, T.W.; van den Engh, G. Kinetic analyses as a critical parameter in defining the side population (SP) phenotype. Exp. Cell Res. 2007, 313, 1921-1926.

32. Huber, M.A.; Kraut, N.; Beug, H. Molecular requirements for epithelial-mesenchymal transition during tumor progression. Curr. Opin. Cell Biol. 2005, 17, 548-558.

33. Christgen, M.; Geffers, R.; Ballmaier, M.; Christgen, H.; Poczkaj, J.; Krech, T.; Kreipe, H.; Lehmann, U. Down-regulation of the fetal stem cell factor SOX17 by H33342: A mechanism responsible for differential gene expression in breast cancer side population cells. J. Biol. Chem. 2010, 285, 6412-6418.

34. Chiba, T.; Miyagi, S.; Saraya, A.; Aoki, R.; Seki, A.; Morita, Y.; Yonemitsu, Y.; Yokosuka, O.; Taniguchi, H.; Nakauchi, H.; Iwama, A. The polycomb gene product BMI1 contributes to the maintenance of tumor-initiating side population cells in hepatocellular carcinoma. Cancer Res. 2008, 68, 7742-7749.

35. Zhou, S.; Schuetz, J.D.; Bunting, K.D.; Colapietro, A.M.; Sampath, J.; Morris, J.J.; Lagutina, I.; Grosveld, G.C.; Osawa, M.; Nakauchi, H.; Sorrentino, B.P. The ABC transporter Bcrp1/ABCG2 is expressed in a wide variety of stem cells and is a molecular determinant of the side-population phenotype. Nat. Med. 2001, 7, 1028-1034.

36. Wu, C.; Alman, B.A. Side population cells in human cancers. Cancer Lett. 2008, 268, 1-9.

37. Patrawala, L.; Calhoun, T.; Schneider-Broussard, R.; Zhou, J.; Claypool, K.; Tang, D.G. Side population is enriched in tumorigenic, stem-like cancer cells, whereas ABCG2+ and ABCG2cancer cells are similarly tumorigenic. Cancer Res. 2005, 65, 6207-6219.

38. Ryan, D.H.; Chapple, C.W.; Kossover, S.A.; Sandberg, A.A.; Cohen, H.J. Phenotypic similarities and differences between CALLA-positive acute lymphoblastic leukemia cells and normal marrow CALLA-positive B cell precursors. Blood 1987, 70, 814-821. 
39. Bachelard-Cascales, E.; Chapellier, M.; Delay, E.; Pochon, G.; Voeltzel, T.; Puisieux, A.; Caron de Fromentel, C.; Maguer-Satta, V. The CD10 enzyme is a key player to identify and regulate human mammary stem cells. Stem Cells 2010, 28, 1081-1088.

40. Wei, X.; Dombkowski, D.; Meirelles, K.; Pieretti-Vanmarcke, R.; Szotek, P.P.; Chang, H.L.; Preffer, F.I.; Mueller, P.R.; Teixeira, J.; MacLaughlin, D.T.; Donahoe, P.K. Mullerian inhibiting substance preferentially inhibits stem/progenitors in human ovarian cancer cell lines compared with chemotherapeutics. Proc. Natl. Acad. Sci. USA 2010, 107, 18874-18879.

41. Guzman-Ramirez, N.; Voller, M.; Wetterwald, A.; Germann, M.; Cross, N.A.; Rentsch, C.A.; Schalken, J.; Thalmann, G.N.; Cecchini, M.G. In vitro propagation and characterization of neoplastic stem/progenitor-like cells from human prostate cancer tissue. Prostate 2009, 69, 1683-1693.

42. Liu, H.; Patel, M.R.; Prescher, J.A.; Patsialou, A.; Qian, D.; Lin, J.; Wen, S.; Chang, Y.F.; Bachmann, M.H.; Shimono, Y.; Dalerba, P.; Adorno, M.; Lobo, N.; Bueno, J.; Dirbas, F.M.; Goswami, S.; Somlo, G.; Condeelis, J.; Contag, C.H.; Gambhir, S.S.; Clarke, M.F. Cancer stem cells from human breast tumors are involved in spontaneous metastases in orthotopic mouse models. Proc. Natl. Acad. Sci. USA2010, 107, 18115-18120.

43. Hebbard, L.; Steffen, A.; Zawadzki, V.; Fieber, C.; Howells, N.; Moll, J.; Ponta, H.; Hofmann, M.; Sleeman, J. CD44 expression and regulation during mammary gland development and function. J. Cell Sci. 2000, 113 (Pt 14), 2619-2630.

44. Godar, S.; Ince, T.A.; Bell, G.W.; Feldser, D.; Donaher, J.L.; Bergh, J.; Liu, A.; Miu, K.; Watnick, R.S.; Reinhardt, F.; McAllister, S.S.; Jacks, T.; Weinberg, R.A. Growth-inhibitory and tumorsuppressive functions of p53 depend on its repression of CD44 expression. Cell 2008, 134, 62-73.

45. Cheng, J.X.; Liu, B.L.; Zhang, X. How powerful is CD133 as a cancer stem cell marker in brain tumors? Cancer Treat. Rev. 2009, 35, 403-408.

46. Yin, A.H.; Miraglia, S.; Zanjani, E.D.; Almeida-Porada, G.; Ogawa, M.; Leary, A.G.; Olweus, J.; Kearney, J.; Buck, D.W. AC133, a novel marker for human hematopoietic stem and progenitor cells. Blood 1997, 90, 5002-5012.

47. Shmelkov, S.V.; Jun, L.; St Clair, R.; McGarrigle, D.; Derderian, C.A.; Usenko, J.K.; Costa, C.; Zhang, F.; Guo, X.; Rafii, S. Alternative promoters regulate transcription of the gene that encodes stem cell surface protein AC133. Blood 2004, 103, 2055-2061.

48. Mizrak, D.; Brittan, M.; Alison, M.R. CD133: molecule of the moment. J. Pathol. 2008, 214, 3-9.

49. Lee, A.; Kessler, J.D.; Read, T.A.; Kaiser, C.; Corbeil, D.; Huttner, W.B.; Johnson, J.E.; Wechsler-Reya, R.J. Isolation of neural stem cells from the postnatal cerebellum. Nat. Neurosci. 2005, 8, 723-729.

50. Sladek, N.E. Human aldehyde dehydrogenases: Potential pathological, pharmacological, and toxicological impact. J. Biochem. Mol. Toxicol. 2003, 17, 7-23.

51. Duester, G.; Mic, F.A.; Molotkov, A. Cytosolic retinoid dehydrogenases govern ubiquitous metabolism of retinol to retinaldehyde followed by tissue-specific metabolism to retinoic acid. Chem. Biol. Interact. 2003, 143-144, 201-210.

52. Ambroziak, W.; Izaguirre, G.; Pietruszko, R. Metabolism of retinaldehyde and other aldehydes in soluble extracts of human liver and kidney. J. Biol. Chem. 1999, 274, 33366-33373. 
53. Armstrong, L.; Stojkovic, M.; Dimmick, I.; Ahmad, S.; Stojkovic, P.; Hole, N.; Lako, M.Phenotypic characterization of murine primitive hematopoietic progenitor cells isolated on basis of aldehyde dehydrogenase activity. Stem Cells 2004, 22, 1142-1151.

54. Hess, D.A.; Meyerrose, T.E.; Wirthlin, L.; Craft, T.P.; Herrbrich, P.E.; Creer, M.H.; Nolta, J.A. Functional characterization of highly purified human hematopoietic repopulating cells isolated according to aldehyde dehydrogenase activity. Blood 2004, 104, 1648-1655.

55. Pearce, D.J.; Taussig, D.; Simpson, C.; Allen, K.; Rohatiner, A.Z.; Lister, T.A.; Bonnet, D. Characterization of cells with a high aldehyde dehydrogenase activity from cord blood and acute myeloid leukemia samples. Stem Cells 2005, 23, 752-760.

56. Awad, O.; Yustein, J.T.; Shah, P.; Gul, N.; Katuri, V.; O'Neill, A.; Kong, Y.; Brown, M.L.; Toretsky, J.A.; Loeb, D.M. High ALDH Activity Identifies Chemotherapy-Resistant Ewing's Sarcoma Stem Cells That Retain Sensitivity to EWS-FLI1 Inhibition. PLoS One 2010, 5, e13943.

57. Charafe-Jauffret, E.; Ginestier, C.; Iovino, F.; Tarpin, C.; Diebel, M.; Esterni, B.; Houvenaeghel, G.; Extra, J.M.; Bertucci, F.; Jacquemier, J.; Xerri, L.; Dontu, G.; Stassi, G.; Xiao, Y.; Barsky, S.H.; Birnbaum, D.; Viens, P.; Wicha, M.S. Aldehyde dehydrogenase 1-positive cancer stem cells mediate metastasis and poor clinical outcome in inflammatory breast cancer. Clin. Cancer Res. 2010, 16, 45-55.

58. Carpentino, J.E.; Hynes, M.J.; Appelman, H.D.; Zheng, T.; Steindler, D.A.; Scott, E.W.; Huang, E.H. Aldehyde dehydrogenase-expressing colon stem cells contribute to tumorigenesis in the transition from colitis to cancer. Cancer Res. 2009, 69, 8208-8215.

59. Schubert, M.; Herbert, N.; Taubert, I.; Ran, D.; Singh, R.; Eckstein, V.; Vitacolonna, M.; Ho, A. D.; Zoller, M. Differential survival of AML subpopulations in NOD/SCID mice. Exp. Hematol. 2011, 39, 250-263

60. Prasmickaite, L.; Engesaeter, B.O.; Skrbo, N.; Hellenes, T.; Kristian, A.; Oliver, N.K.; Suo, Z.; Maelandsmo, G.M. Aldehyde dehydrogenase (ALDH) activity does not select for cells with enhanced aggressive properties in malignant melanoma. PLoS One 2010, 5, e10731.

61. Yu, F.; Yao, H.; Zhu, P.; Zhang, X.; Pan, Q.; Gong, C.; Huang, Y.; Hu, X.; Su, F.; Lieberman, J.; Song, E. let-7 regulates self renewal and tumorigenicity of breast cancer cells. Cell 2007, 131, 1109-1123.

62. Shimono, Y.; Zabala, M.; Cho, R.W.; Lobo, N.; Dalerba, P.; Qian, D.; Diehn, M.; Liu, H.; Panula, S.P.; Chiao, E.; Dirbas, F.M.; Somlo, G.; Pera, R.A.; Lao, K.; Clarke, M.F. Downregulation of miRNA-200c links breast cancer stem cells with normal stem cells. Cell 2009, 138, 592-603.

63. Iliopoulos, D.; Hirsch, H.A.; Struhl, K. An epigenetic switch involving NF-kappaB, Lin28, Let-7 MicroRNA, and IL6 links inflammation to cell transformation. Cell 2009, 139, 693-706.

64. Iliopoulos, D.; Lindahl-Allen, M.; Polytarchou, C.; Hirsch, H.A.; Tsichlis, P.N.; Struhl, K. Loss of miR-200 inhibition of Suz12 leads to polycomb-mediated repression required for the formation and maintenance of cancer stem cells. Mol. Cell 2010, 39, 761-772.

65. Garzia, L.; Andolfo, I.; Cusanelli, E.; Marino, N.; Petrosino, G.; De Martino, D.; Esposito, V.; Galeone, A.; Navas, L.; Esposito, S.; Gargiulo, S.; Fattet, S.; Donofrio, V.; Cinalli, G.; Brunetti, A.; Vecchio, L.D.; Northcott, P.A.; Delattre, O.; Taylor, M.D.; Iolascon, A.; Zollo, M. MicroRNA-199b-5p impairs cancer stem cells through negative regulation of HES1 in medulloblastoma. PLoS One 2009, 4, e4998. 
66. Guessous, F.; Zhang, Y.; Kofman, A.; Catania, A.; Li, Y.; Schiff, D.; Purow, B.; Abounader, R. microRNA-34a is tumor suppressive in brain tumors and glioma stem cells. Cell Cycle 2010, 9, 1031-1036.

67. Li, W.Q.; Li, Y.M.; Tao, B.B.; Lu, Y.C.; Hu, G.H.; Liu, H.M.; He, J.; Xu, Y.; Yu, H.Y. Downregulation of ABCG2 expression in glioblastoma cancer stem cells with miRNA-328 may decrease their chemoresistance. Med. Sci. Monit. 2010, 16, HY. 27-30.

68. Venkataraman, S.; Alimova, I.; Fan, R.; Harris, P.; Foreman, N.; Vibhakar, R. MicroRNA 128a increases intracellular ROS level by targeting Bmi-1 and inhibits medulloblastoma cancer cell growth by promoting senescence. PLoS One 2010, 5, e10748.

69. Ji, J.; Yamashita, T.; Budhu, A.; Forgues, M.; Jia, H.L.; Li, C.; Deng, C.; Wauthier, E.; Reid, L.M.; Ye, Q.H.; Qin, L.X.; Yang, W.; Wang, H.Y.; Tang, Z.Y.; Croce, C.M.; Wang, X.W. Identification of microRNA-181 by genome-wide screening as a critical player in EpCAM-positive hepatic cancer stem cells. Hepatology 2009, 50, 472-480.

70. Ji, Q.; Hao, X.; Zhang, M.; Tang, W.; Yang, M.; Li, L.; Xiang, D.; Desano, J.T.; Bommer, G.T.; Fan, D.; Fearon, E.R.; Lawrence, T.S.; Xu, L. MicroRNA miR-34 inhibits human pancreatic cancer tumor-initiating cells. PLoS One 2009, 4, e6816.

71. Song, B.; Wang, Y.; Xi, Y.; Kudo, K.; Bruheim, S.; Botchkina, G.I.; Gavin, E.; Wan, Y.; Formentini, A.; Kornmann, M.; Fodstad, O.; Ju, J. Mechanism of chemoresistance mediated by miR-140 in human osteosarcoma and colon cancer cells. Oncogene 2009, 28, 4065-4074.

72. Song, B.; Wang, Y.; Titmus, M.A.; Botchkina, G.; Formentini, A.; Kornmann, M.; Ju, J. Molecular mechanism of chemoresistance by miR-215 in osteosarcoma and colon cancer cells. Mol. Cancer 2010, 9, 96.

73. Dalerba, P.; Dylla, S.J.; Park, I.K.; Liu, R.; Wang, X.; Cho, R.W.; Hoey, T.; Gurney, A.; Huang, E.H.; Simeone, D.M.; Shelton, A.A.; Parmiani, G.; Castelli, C.; Clarke, M.F. Phenotypic characterization of human colorectal cancer stem cells. Proc. Natl. Acad. Sci. USA 2007, 104, 10158-10163.

74. Harper, L.J.; Piper, K.; Common, J.; Fortune, F.; Mackenzie, I.C. Stem cell patterns in cell lines derived from head and neck squamous cell carcinoma. J. Oral. Pathol. Med. 2007, 36, 594-603.

75. Shinoe, T.; Kuribayashi, H.; Saya, H.; Seiki, M.; Aburatani, H.; Watanabe, S. Identification of CD44 as a cell surface marker for Muller glia precursor cells. J. Neurochem. 2010, 115, 1633-1642.

76. Majeti, R. Monoclonal antibody therapy directed against human acute myeloid leukemia stem cells. Oncogene 2011, 30, 1009-19.

77. Vazquez-Martin, A.; Oliveras-Ferraros, C.; Cufi, S.; Del Barco, S.; Martin-Castillo, B.; Menendez, J.A. Metformin regulates breast cancer stem cell ontogeny by transcriptional regulation of the epithelial-mesenchymal transition (EMT) status. Cell Cycle 2010, 9, 3807-3814.

78. Wellner, U.; Schubert, J.; Burk, U.C.; Schmalhofer, O.; Zhu, F.; Sonntag, A.; Waldvogel, B.; Vannier, C.; Darling, D.; zur Hausen, A.; Brunton, V.G.; Morton, J.; Sansom, O.; Schuler, J.; Stemmler, M.P.; Herzberger, C.; Hopt, U.; Keck, T.; Brabletz, S.; Brabletz, T. The EMT-activator ZEB1 promotes tumorigenicity by repressing stemness-inhibiting microRNAs. Nat. Cell. Biol. 2009, 11, 1487-1495. 
79. Thiery, J.P.; Acloque, H.; Huang, R.Y.; Nieto, M.A. Epithelial-mesenchymal transitions in development and disease. Cell 2009, 139, 871-890.

80. Malanchi, I.; Peinado, H.; Kassen, D.; Hussenet, T.; Metzger, D.; Chambon, P.; Huber, M.; Hohl, D.; Cano, A.; Birchmeier, W.; Huelsken, J. Cutaneous cancer stem cell maintenance is dependent on beta-catenin signalling. Nature 2008, 452, 650-653.

81. Kitamura, H.; Okudela, K.; Yazawa, T.; Sato, H.; Shimoyamada, H. Cancer stem cell: implications in cancer biology and therapy with special reference to lung cancer. Lung Cancer 2009, 66, 275-281.

82. Kudo-Saito, C.; Shirako, H.; Takeuchi, T.; Kawakami, Y. Cancer metastasis is accelerated through immunosuppression during Snail-induced EMT of cancer cells. Cancer Cell 2009, 15, 195-206.

83. Mani, S.A.; Guo, W.; Liao, M.J.; Eaton, E.N.; Ayyanan, A.; Zhou, A.Y.; Brooks, M.; Reinhard, F.; Zhang, C.C.; Shipitsin, M.; Campbell, L.L.; Polyak, K.; Brisken, C.; Yang, J.; Weinberg, R.A. The epithelial-mesenchymal transition generates cells with properties of stem cells. Cell 2008, 133, 704-715.

84. Santisteban, M.; Reiman, J.M.; Asiedu, M.K.; Behrens, M.D.; Nassar, A.; Kalli, K.R.; Haluska, P.; Ingle, J.N.; Hartmann, L.C.; Manjili, M.H.; Radisky, D.C.; Ferrone, S.; Knutson, K.L. Immune-induced epithelial to mesenchymal transition in vivo generates breast cancer stem cells. Cancer Res. 2009, 69, 2887-2895.

85. Heldin, C.H.; Landstrom, M.; Moustakas, A. Mechanism of TGF-beta signaling to growth arrest, apoptosis, and epithelial-mesenchymal transition. Curr. Opin. Cell Biol. 2009, 21, 166-176.

86. Akhurst, R.J.; Derynck, R. TGF-beta signaling in cancer-A double-edged sword. Trends Cell Biol. 2001, 11, S44-S51.

87. Padua, D.; Massague, J. Roles of TGFbeta in metastasis. Cell Res. 2009, 19, 89-102.

88. Verschueren, K.; Huylebroeck, D. Remarkable versatility of Smad proteins in the nucleus of transforming growth factor-beta activated cells. Cytokine Growth Factor Rev. 1999, 10, 187-199.

89. Comijn, J.; Berx, G.; Vermassen, P.; Verschueren, K.; van Grunsven, L.; Bruyneel, E.; Mareel, M.; Huylebroeck, D.; van Roy, F. The two-handed E box binding zinc finger protein SIP1 downregulates E-cadherin and induces invasion. Mol. Cell 2001, 7, 1267-1278.

90. Postigo, A.A. Opposing functions of ZEB proteins in the regulation of the TGFbeta/BMP signaling pathway. Embo J. 2003, 22, 2443-2452.

91. Vandewalle, C.; Van Roy, F.; Berx, G. The role of the ZEB family of transcription factors in development and disease. Cell Mol. Life Sci. 2009, 66, 773-787.

92. Patel, S.A.; Meyer, J.R.; Greco, S.J.; Corcoran, K.E.; Bryan, M.; Rameshwar, P. Mesenchymal stem cells protect breast cancer cells through regulatory $\mathrm{T}$ cells: role of mesenchymal stem cell-derived TGF-beta. J. Immunol. 2010, 184, 5885-5894.

93. Kim, E.S.; Kim, M.S.; Moon, A. TGF-beta-induced upregulation of MMP-2 and MMP-9 depends on p38 MAPK, but not ERK signaling in MCF10A human breast epithelial cells. Int. J. Oncol. 2004, 25, 1375-1382.

94. Adorno, M.; Cordenonsi, M.; Montagner, M.; Dupont, S.; Wong, C.; Hann, B.; Solari, A.; Bobisse, S.; Rondina, M.B.; Guzzardo, V.; Parenti, A.R.; Rosato, A.; Bicciato, S.; Balmain, A.; 
Piccolo, S. A Mutant-p53/Smad complex opposes p63 to empower TGFbeta-induced metastasis. Cell 2009, 137, 87-98.

95. Adams, B.D.; Guttilla, I.K.; White, B.A. Involvement of microRNAs in breast cancer. Semin. Reprod. Med. 2008, 26, 522-536.

96. Shi, M.; Liu, D.; Duan, H.; Shen, B.; Guo, N. Metastasis-related miRNAs, active players in breast cancer invasion, and metastasis. Cancer Metastasis Rev. 2010, 29, 785-799.

97. Lee, R.C.; Feinbaum, R.L.; Ambros, V. The C. elegans heterochronic gene lin-4 encodes small RNAs with antisense complementarity to lin-14. Cell 1993, 75, 843-854.

98. Reinhart, B.J.; Slack, F.J.; Basson, M.; Pasquinelli, A.E.; Bettinger, J.C.; Rougvie, A.E.; Horvitz, H.R.; Ruvkun, G. The 21-nucleotide let-7 RNA regulates developmental timing in Caenorhabditis elegans. Nature 2000, 403, 901-906.

99. Sampson, V.B.; Rong, N.H.; Han, J.; Yang, Q.; Aris, V.; Soteropoulos, P.; Petrelli, N.J.; Dunn, S.P.; Krueger, L.J. MicroRNA let-7a down-regulates MYC and reverts MYC-induced growth in Burkitt lymphoma cells. Cancer Res. 2007, 67, 9762-9770.

100. Zhong, X.; Li, N.; Liang, S.; Huang, Q.; Coukos, G.; Zhang, L. Identification of microRNAs regulating reprogramming factor LIN28 in embryonic stem cells and cancer cells. J. Biol. Chem. 2010, 285, 41961-41971.

101. Ma, L.; Young, J.; Prabhala, H.; Pan, E.; Mestdagh, P.; Muth, D.; Teruya-Feldstein, J.; Reinhardt, F.; Onder, T.T.; Valastyan, S.; Westermann, F.; Speleman, F.; Vandesompele, J.; Weinberg, R.A. miR-9, a MYC/MYCN-activated microRNA, regulates E-cadherin and cancer metastasis. Nat. Cell Biol. 2010, 12, 247-256.

102. Yu, F.; Deng, H.; Yao, H.; Liu, Q.; Su, F.; Song, E. Mir-30 reduction maintains self-renewal and inhibits apoptosis in breast tumor-initiating cells. Oncogene 2010, 29, 4194-4204.

103. Huang, Q.; Gumireddy, K.; Schrier, M.; le Sage, C.; Nagel, R.; Nair, S.; Egan, D.A.; Li, A.; Huang, G.; Klein-Szanto, A.J.; Gimotty, P.A.; Katsaros, D.; Coukos, G.; Zhang, L.; Pure, E.; Agami, R. The microRNAs miR-373 and miR-520c promote tumour invasion and metastasis. Nat. Cell Biol. 2008, 10, 202-210.

104. Liu, C.; Zhao, G.; Liu, J.; Ma, N.; Chivukula, P.; Perelman, L.; Okada, K.; Chen, Z.; Gough, D.; $\mathrm{Yu}, \mathrm{L}$. Novel biodegradable lipid nano complex for siRNA delivery significantly improving the chemosensitivity of human colon cancer stem cells to paclitaxel. J. Control Release 2009, 140, 277-283.

105. Upadhyay, K.K.; Bhatt, A.N.; Mishra, A.K.; Dwarakanath, B.S.; Jain, S.; Schatz, C.; Le Meins, J.F.; Farooque, A.; Chandraiah, G.; Jain, A.K.; Misra, A.; Lecommandoux, S. The intracellular drug delivery and anti tumor activity of doxorubicin loaded poly(gamma-benzyl L-glutamate)-b-hyaluronan polymersomes. Biomaterials 2010, 31, 2882-2892.

106. Zhang, X.; Roth, M.J. Antibody-directed lentiviral gene transduction in early immature hematopoietic progenitor cells. J. Gene Med. 2010, 12, 945-955.

107. Honma, K.; Iwao-Koizumi, K.; Takeshita, F.; Yamamoto, Y.; Yoshida, T.; Nishio, K.; Nagahara, S.; Kato, K.; Ochiya, T. RPN2 gene confers docetaxel resistance in breast cancer. Nat. Med. 2008, $14,939-948$. 
108. Riccioni, R.; Dupuis, M.L.; Bernabei, M.; Petrucci, E.; Pasquini, L.; Mariani, G.; Cianfriglia, M.; Testa, U. The cancer stem cell selective inhibitor salinomycin is a p-glycoprotein inhibitor. Blood Cells Mol. Dis. 2010, 45, 86-92.

109. Hirsch, H.A.; Iliopoulos, D.; Tsichlis, P.N.; Struhl, K. Metformin selectively targets cancer stem cells, and acts together with chemotherapy to block tumor growth and prolong remission. Cancer Res. 2009, 69, 7507-7511.

110. Gonzalez-Angulo, A.M.; Meric-Bernstam, F. Metformin: a therapeutic opportunity in breast cancer. Clin. Cancer Res. 2010, 16, 1695-1700.

111. Hadad, S.M.; Fleming, S.; Thompson, A.M. Targeting AMPK: a new therapeutic opportunity in breast cancer. Crit. Rev. Oncol. Hematol. 2008, 67, 1-7.

112. Cripe, T.P.; Wang, P.Y.; Marcato, P.; Mahller, Y.Y.; Lee, P.W. Targeting cancer-initiating cells with oncolytic viruses. Mol. Ther. 2009, 17, 1677-182.

113. Nakao, A.; Kasuya, H.; Sahin, T.T.; Nomura, N.; Kanzaki, A.; Misawa, M.; Shirota, T.; Yamada, S.; Fujii, T.; Sugimoto, H.; Shikano, T.; Nomoto, S.; Takeda, S.; Kodera, Y.; Nishiyama, Y. A phase I dose-escalation clinical trial of intraoperative direct intratumoral injection of HF10 oncolytic virus in non-resectable patients with advanced pancreatic cancer. Cancer Gene Ther. 2011, 18, 167-175.

114. Ausubel, L.J.; Meseck, M.; Derecho, I.; Lopez, P.; Knoblauch, C.; McMahon, R.; Anderson, J.; Dunphy, N.; Quezada, V.; Khan, R.; Dang, W.; Luo, M.; Hsu, D.; Woo, S.; Couture, L. cGMP Production of an Oncolytic rVSV Vector for Cancer Treatment. Hum. Gene. Ther. 2010, 22, 1-9.

115. Thorne, S.H.; Liang, W.; Sampath, P.; Schmidt, T.; Sikorski, R.; Beilhack, A.; Contag, C.H. Targeting localized immune suppression within the tumor through repeat cycles of immune cell-oncolytic virus combination therapy. Mol. Ther. 2010, 18, 1698-1705.

116. Eriksson, M.; Guse, K.; Bauerschmitz, G.; Virkkunen, P.; Tarkkanen, M.; Tanner, M.; Hakkarainen, T.; Kanerva, A.; Desmond, R.A.; Pesonen, S.; Hemminki, A. Oncolytic adenoviruses kill breast cancer initiating CD44+CD24-/low cells. Mol. Ther. 2007, 15, 2088-93.

117. Marcato, P.; Dean, C.A.; Giacomantonio, C.A.; Lee, P.W. Oncolytic reovirus effectively targets breast cancer stem cells. Mol. Ther. 2009, 17, 972-979.

118. Ahtiainen, L.; Mirantes, C.; Jahkola, T.; Escutenaire, S.; Diaconu, I.; Osterlund, P.; Kanerva, A.; Cerullo, V.; Hemminki, A. Defects in innate immunity render breast cancer initiating cells permissive to oncolytic adenovirus. PLoS One 2010, 5, e13859.

(C) 2011 by the authors; licensee MDPI, Basel, Switzerland. This article is an open access article distributed under the terms and conditions of the Creative Commons Attribution license (http://creativecommons.org/licenses/by/3.0/). 